Manuscript of the article: Ádám A., Novák A., Prácser E., Szarka L., Wesztergom V., Indication of meta-anthracite by magnetotellurics in the Köszeg-Rechnitz Penninic window: a test area.

Acta Geodaetica et Geophysica, 2013, 48:(3) pp. 281-292., DOI:10.1007/s40328-013-0028-2

\title{
INDICATION OF META-ANTHRACITE BY MAGNETOTELLURICS IN THE KÖSZEG-RECHNITZ PENNINIC WINDOW: A TEST AREA
}

\author{
Ádám A., Novák A., Prácser E., Szarka L., Wesztergom V. \\ Geodetic and Geophysical Institute, Research Centre for Astronomy and Earth Sciences, \\ Hungarian Academy of Sciences, Sopron
}

\begin{abstract}
One of the Penninic Nappes is the Köszeg-Rechnitz (K-R) tectonic window at the Eastern end of the Eastern Alps. It has a complicated metamorphic history from the Jurassic time. The organic material of the Penninic Ocean was transformed to electrically conductive meta-anthracite. Its amount in the chalcophyllite is estimated by geochemists to 0.2 per cent.

Taking this conducting structure as a test area pilot deep magnetotelluric (MT) soundings have been carried out and we determined

- the structure of the conductivity anomaly due to 0.2 per cent meta anthracite in the $K-R$ window and its surroundings

- the different kinds of MT distortions as lateral (side) effect of the conductor appearing in the crust and mantle

- the most probable depth of the conductive asthenosphere at the border of the Pannonian Basin (having extreme shallow asthenosphere). The obtained $\sim 140 \mathrm{~km}$ depth is in correlation with value of the asthenospheric map based mainly on seismic data.
\end{abstract}

Keywords: magnetotelluric sounding; meta-anthracite; graphite; conductivity anomaly; Köszeg-Rechnitz tectonic window; 1D and 2D inversion

\section{INTRODUCTION}

Characteristic features of geophysical methods are usually studied in test areas, which are tectonically i.e. geometrically and mineralogically well known. For the magnetotelluric deep soundings the Köszeg-Rechnitz window (K-R), a characteristic geological structure, could be a suitable test area. This graphitic (meta-anthracite) conductive body is situated at the Austrian-Hungarian border (Figure 1). Six MT deep soundings as pilot measurements (shortly mentioned among others in Ádám, et al. 2008) were carried out close to the present research area, in order to prepare a more detailed study. The main objectives of this pilot measurements were as follows:

- to indicate the conductor and its lateral effect (side effect) compared with geological information,

- to analyze the different kinds of MT distortions,

- to determine those extreme MT sounding curves, which hold the deepest real information (e.g. indication of the asthenosphere), in correlation with the seismic investigation.

\section{GEOLOGY OF THE PENNINIC WINDOW}

The Penninic Nappes, which are overlain by thick stack Austro-Alpine Units, are exposed at the Eastern end of the Eastern Alps in the tectonic windows of the Köszeg-Rechnitz and Eisenberg (and in two others windows). This Penninic window contains a reduced 
metamorphic ophiolite sequence and a meta-sedimentary cover $(\sim 3000 \mathrm{~m})$ of the former South Penninic Ocean, which was opened during the Early-Middle Jurassic period, subducted and closed in the Late Cretaceous-Early Tertiary. The Upper Nappe in the K-R window - in our study area - consists of chalcophyllite, graphite-phyllite and chlorite phyllite which are overlain by greenshist. The Lower Nappe is composed mainly of quartz-phyllite (Ivancsics J., Török K., 2001; Pahr A., 1984). The main rock forming minerals of the chalcphyllite often contain small meta-anthracite flakes as inclusions. The role of graphite in the geodynamics is given e.g. by Glover and Ádám (2008).For the meta-anthracite content about 0.2 per cent was obtained from geochemical estimations.

\section{DATA}

\section{Characteristics of the MT sounding curves (Fig. 2)}

In the area of the K-R window (see in Fig. $1 \mathrm{Gl}$ and AL points) the Rho minimum resistivity values supposed to be TE mode ones are under $10 \mathrm{Ohmm}$ in the whole measured period range $\left(10-10^{4} \mathrm{sec}\right)$, indicating the graphite (meta anthracite) in the more resistive phyllites. Outside of the window the resistivity is higher than $10 \mathrm{Ohmm}$. MT site Althodis (Al) lies just at the boundary of the "conductive" window. As in general case, near the edge of a conductive body the electric charges accumulate and consequently the resistivity values increase in the TM mode and the difference between the extreme sounding curves also increases. (A similar effect was discussed by Ádám et al. (2000) concerning the outcrop of the Transdanubian Conductivity Anomaly (TCA) in Aszófö, Hungary). Generally Rho maximum curves (the TM mode ones) are less sensitive to the small graphitic lenses.

\section{Direction of the Rho minimum values (TE mode)}

The northwest direction inside and in the close vicinity of the K-R window is clearly separated from that of the other measuring sites, having northeast direction (Fig. 3). The direction of MT site Althodis is a special case: it is north-south directed (see its explanation under I.). At the MT sites inside the conductor the TE mode (Rho minimum) direction crosses the conductor. The same direction of MT site Unterrabnitz (Un) as in MT site Glasshütten (Gl) could be the indication of the northward continuation of the conductive window covered by a thin other formation.

\section{INDICATION OF CRUSTAL AND MANTLE CONDUCTIVITY ANOMALIES BASED ON 1D INVERSION (Fig. 4 and Table 1)}

- The near-surface graphite is indicated as a very good electric conductor in the upper $10 \mathrm{~km}$. At MT site Glasshütten the layer sequence of the Rho minimum curve confirms the geological statement of Haas (2001): the graphitic phyllites are intercalations in the more resistive quartz-phyllite.

- There is a slight resistivity decrease in the layer sequence of the TE mode (Rhomin) curves in the depth ranges of the seismic crustal discontinuities $(20-40 \mathrm{~km}$; Weber et al., 1996). It seems that there is any trend between the depth of the "apparent crustal conductors" and their distance from the near-surface graphitic conductors in K-R window. The distortion - especially in the sites Gl and Al - most probably influences the depth of the conducting asthenosphere in TE mode, elevating it to crustal depth ranges.

- At MT sites Kt and Km crustal or near-crustal conductors appear in both polarizations. Near-crustal conductors are shown also by 2D inversion. The probability of their presence is supported by the MT measurements in the nearby station "Rehgraben" in the Graz basin at about $10 \mathrm{~km}$ distance from the south segment of our profile (Ádám et al., 1981). Their cause as a mid-crustal ductile zone is to be further studied. 
- A real deep conductor appears in the Rho maximum (TM mode) curves at an averages depth of $140 \mathrm{~km}$ (except at $\mathrm{Al}$ and Ko, see Fig. 4). This depth value of the asthenosphere fits quite well with mainly seismic data in the area of the Penninicum (See on the map of the asthenosphere of the Pannonian Basin and the neighbouring areas (Horváth et al., 2006)).

\section{DIMENSIONAL ANALYSIS}

The K-R window is a fully anisotropic and inhomogeneous subsurface structure. To define its geometry (dimension) two invariant parameters were calculated in dimension analysis: the Bahr-Q (Bahr, 1988; Bahr, 1991; Prácser and Szarka, 1999; Weaver, Agarwal Lilley, 2000) invariant dimensionality indicators, and the phase tensor ellipses (Caldwell et al, 2004; Marti I Castells, 2006).

The Bahr-Q (WAL) dimensionality indicators show this area mainly as it would be twodimensional. At longer periods the invariants have - beside some $1 \mathrm{D}$ and non-classifiable indication - three-dimensional character mostly near the K-R window with a transition to 3D/2D geometry (Fig. 5).

The phase tensor ellipse, as it is known, is one of the most informative invariant parameters, which indicates the dimensionality of subsurface structures. It is free of galvanic distortion and, in addition, it is not influenced by small subsurface anomalies (Berdichevsky and Dmitriev, 1976). The phase tensor ellipses are in correlation with the Bahr-Q and WAL invariants, in our case, too. In case of 2D structures the elongations of the ellipses represent the geological strike. At longer periods, near K-R window and in the south direction of the area, the ellipses change to indicate 3D structure. This is supported by the non-zero values of the $\beta$ p skew angle (Fig.6).

\section{D INVERSION}

In spite of the fact that the K-R window is a typical 3D geological structure, the dimensional analysis allows to make 2D inversion, and separate the real phenomena from the distortion in the crust and mantle. The near-surface structure was determined by WinGLink inversion technique (Rodi and Mackie, 2001) and the asthenosphere was approximated by REBOCC inversion (Siripunvaraporn and Egbert, 2000; Siripunvaraporn et al. 2005):

- Inversion of the Rho minimum curves (TE mode, shown in Figure 7a) clearly shows the near-surface conductors in the central part of the profile and further to the South of $\mathrm{K}-\mathrm{R}$ window in the MT site Kotezichen which lies close to another small window, the so-called Eisenberg. In the special case of MT site Althodis the conductor almost disappears due to the distortion at the boundary of the K-R window. The inversion results can be seen in another scale (Fig.7b) emphasizing the conductors.

- The inversion of the Rho maximum curves does not show any near-surface conductors, but it shows crustal conductors at both sides of the near-surface graphitic conductors.

- The bimodal - TE and TM joint - inversion (Fig.7) can be described with two effects:

1. The near surface conductors are similar as in case of the TE mode inversion,

2. Similarly to the TM mode inversion, crustal conductors appear as deepening with the distance from the near-surface conductors. The reality of this phenomenon is to be further studied, assuming it as mid-crustal ductile zone.

The conductive asthenophere is well determined by REBOCC inversion in accordance with the seismic asthenospheric map at a depth of 140-150 km (Fig.8). 


\section{CONCLUSIONS}

1. In the Köszeg-Rechnitz window contains electrically conductive graphitic intercalations in the upper $10 \mathrm{~km}$ layer sequence. Its effect well appears in the magnetotelluric deep soundings as conductors, manifesting themselves with electrical resistivity values lower than $10 \mathrm{Ohmm}$.

2. Crustal conductors deepening with distance from the near-surface conductors are clearly indicated by the TM mode (and joint) inversions. It is supposed as a crustal ductile zone, but it needs further studies, because it may be merely an EM distortion.

3. The conductive asthenosphere is indicated at the depth of about $140 \mathrm{~km}$ both by $1 \mathrm{D}$ and 2D inversions of the TM mode MTS curves, in correlation with earlier seismic results.

4. As it has been shown by figures and by the Rho values in the Table 1 the Rho minimum sounding curves well approximate the expected Rho value of the $0.2 \mathrm{pc}$ meta-anthracite.

5. In case of such a complicate structure as K-R one 2D inversions are very qualitative, nevertheless in some cases and in our one also could be valuable approximation of the real structure. 


\section{REFERENCES}

Ádám A., Kolhbeck F., Novák A., Szarka L., 2008: Interpretation of the deep magnetotelluric soundings along the Austrian part of the CELEBRATION-007 profile. Acta Geodaetica et Geophysica Hungarica, 43, 17-32, DOI 10.1556/AGeod.43.2008.1.2.

Ádám A., Märcz F., Verő J., Wallner Á., Duma G., Gutdeutsch R., 1981: Magnetotelluric sounding in the Transitional Zone between the Eastern Alps and Pannonian Basin. $J$. Geophys. 50, 37-44.

Ádám A., Verő L., Wesztergom V., 2000: Behaviour of the magnetotelluric (MT) soundings curves at the southern boundary of the Transdanubian Conductivity Anomaly (TCA) and its remote effect (Regional MT anisotropy), Acta Geodaetica et Geophysica Hungarica, 35(2), pp. 177-194.

Bahr K., 1988: Interpretation of the magnetotelluric impedance tensor: regional induction and local telluric distortion. J. Geophys. 62, pp. 119-127.

Bahr K. 1991: Geological noise in magnetotelluric data: a classification of distortion types. Phys. Earth Planet. Inter. 66, pp. 24-38.

Berdichevsky, M.N., Dmitriev, V.I., 1976: Basic principles of interpretation of magnetotelluric curves. Geoelectric and Geothermal Studies, pp. 165-221, ed. A. Ádám, KAPG Geophysical Monograph, Akadémiai Kiadó, Budapest.

Caldwell, T. G., Bibby H.M, Brown, C., 2004: The Magnetotelluric Phase Tensor. Geophys. J. Int., 158, pp. 457-469.

Glover P.W., Ádám A., 2008: Correlation between crustal high conductivity zones and seismic activity and the role of carbon during shear deformation. J. Geophys, Res. 113., B12210 doi 10.1029/2008JB005804.

Haas J., ED., 2001: Geology of Hungary, Eötvös University Press, Budapest.

Horváth F., Bada G., Szafián P., Tari G., Ádám A. and Cloetingh S., 2006: Formation and deformation of the Pannonian Basin constraints from observation data. In Gee. D. F., and Stephenson, R.A. (eds.) European Lithosphere Dynamics. London: Geological society, Memories no. 32, pp. 191-206.

Iváncsics J., Török K., 2001: Penninic Units in the Köszeg-Rechnitz and Vashegy (Eisenberg) window. In: Ádám A., Szarka L., (eds) PANCARDI 2001, I. Field Quide, pp. 38-47

Kroll A., Flügel H.W., Seiberl W., Weber F., Walach G. and Zych D., 1988: Erlauterungen zu den Karten über den pratertiaren Untergrund des steirischen Beckens und der sudburgenlandischen Schwelle: Geologische Karte der Republik Österreich, Geologische Bundesanstalt, Vienna, scale: 1:200,000.

Marti I Castells A., 2006: A Magnetotelluric Investigation of Geoelectrical Dimensionality and Study of the Central Betic Crustal Structure. Ph.D. thesis, Universitat de Barcelona, Barcelona.

Pahr A., 1984: Erläuterungen zu Blat 137. Oberwart. Geologische Bundesanstalt, Wien, pp. 147.

Prácser E., Szarka L., 1999: A correction to Bahr's "phase deviation" method for tensor decomposition. Earth Planets Space 51, pp. 1019-1022.

Rodi W.L., Mackie R.L., 2001: Nonlinear conjugate gradients algorithm for 2-D magnetotelluric inversion. Geophysics 66, pp. 174-187.

Siripunvaraporn, W., Egbert, G., 2000: An efficient data-subspace inversion method for twodimensional magnetotelluric data. Geophysics, 65, pp. 791-803.

Siripunvaraporn, W., Egbert, G., Uyeshima, M., 2005b: Interpretation of two-dimensional magnetotelluric profile data with three-dimensional inversion: synthetic examples. Geophys. J. Int., 160, pp. 804-814. 
Weaver J.T., Agarwal A.K., Lilley F.E.M., 2000: Characterization of the magnetotelluric tensor in terms of its invariants. Geophysical Journal International 141, pp. 321-337.

Weber F., Schmöller R., and Fruhwirth R.K., 1996: Results of a deep reflection seismic measurement south of Rechnitz/Burgenland/Austria, Geophys. Trans., 40, 79-93.

\section{ACKNOWLEDGEMENT}

One of the co-authors (A. Novák) is a grantee of the János Bolyai Scholarship, Hungarian Academy of Sciences. This study was supported by the TAMOP-4.2.2.C-11/1/KONV-20120015 (Earth-system) project sponsored by the EU and European Social Foundation. The authors thank to J. Szendröi for her participation in the data processing. 


\section{FIGURES}

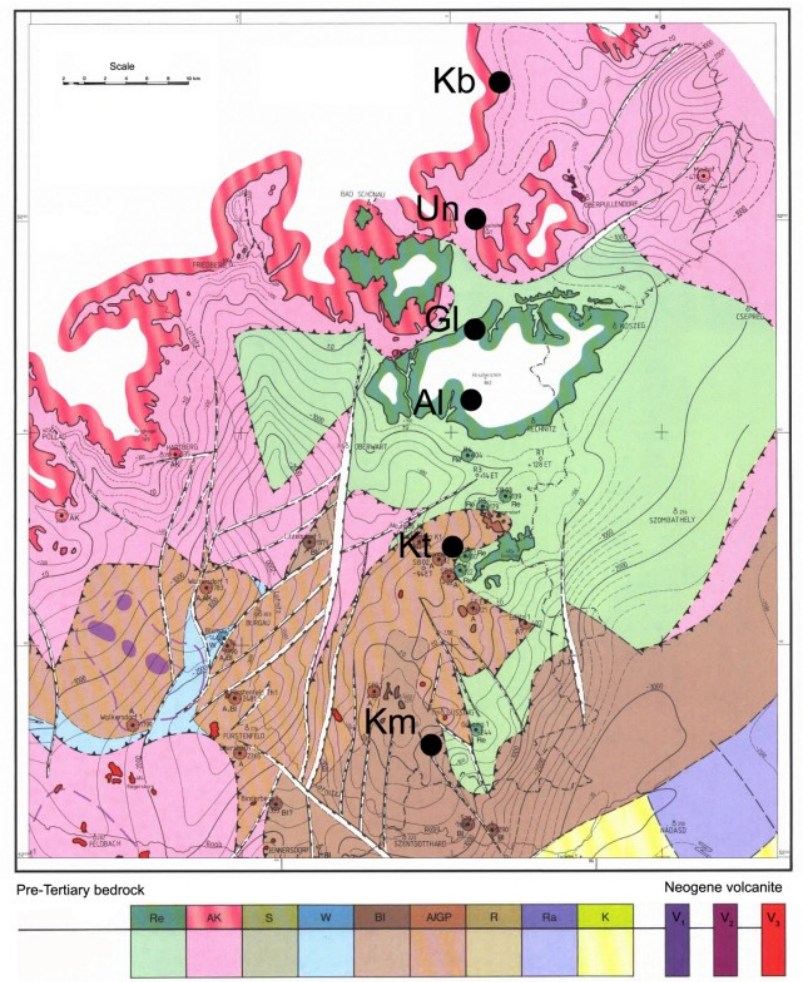

Figure 1.: Geology map of the research area (Guas-Krüger projection M34): The green area represents the Penninic nappes: The outcroped K-R window is bordered by a thick dark green line. Its area was undertaken by detailed geological study including boreholes (Kroll A., et al, 1988). MT sites: Kobersdof (Ko), Unterrabnitz (Un), Glasshütten (Gl), Althodis (Al), Kötezicken (Kt), Kleinmürbish (Km). Geological units: Re - Rechnitz Group (Peninnic Formation), AK - Austroalpine Crystallin, S - Sausal-Group (Phyllitic Paleozoicum), W Wollsdorf Metabasite-Formation (Silur?), Bl - Blumau Phyillite-Carbonat-Formation (U.Silur/L.Devon), A/GP - Arnwiesen Group, Graz Paleozoicum (Carbonatic Devon), R - Radochen Layers (Carbon?), Ra - Radkersburg Group (Permomesozoicum), K - Cretaceous from Kainach und Bakony-Unit, $\mathrm{V}_{1}$ - Latite etc. (Karpat/L. Baden), $\mathrm{V}_{2}$ - Bazanite etc. (Plio-/Pleistocene), $\mathrm{V}_{3}$ - Basalttuffe (Plio-/Pleistocene).
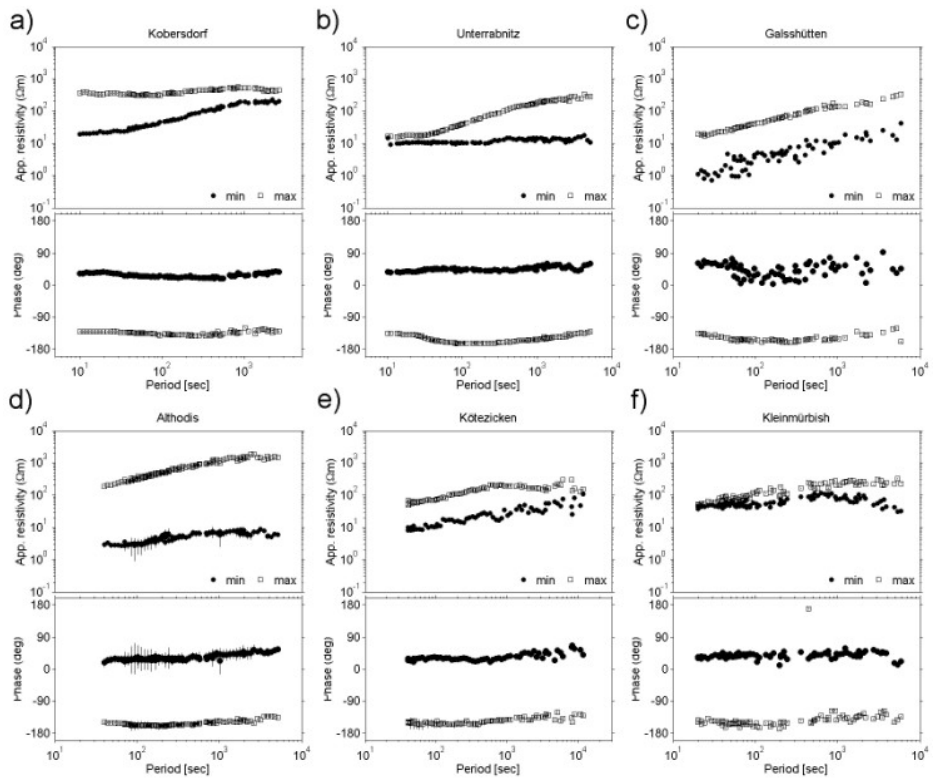

Figure 2.: Rho min (supposed TE) and Rho max (supposed TM) MT sounding curves: outside of the K-R window (Kobersdorf, Kötezicken, Kleinmürbish); inside of the K-R window (Glasshütten, Althodis, and the nearby Unterrabnitz). 


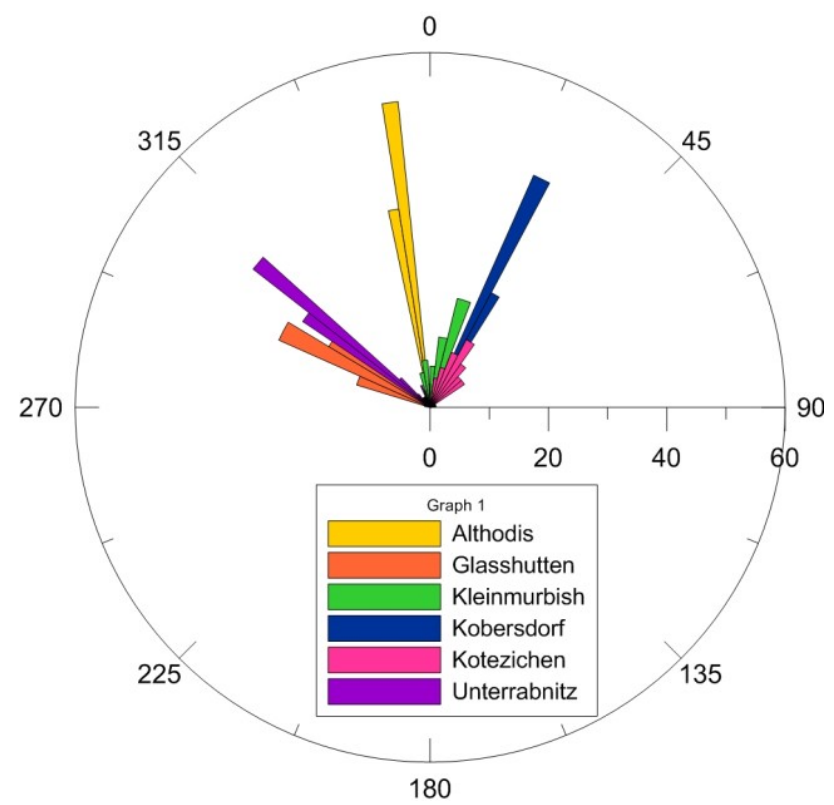

Figure 3.: Distribution of the Rho minimum direction calculated from all processed frequencies. The lengths of the arrows are given.

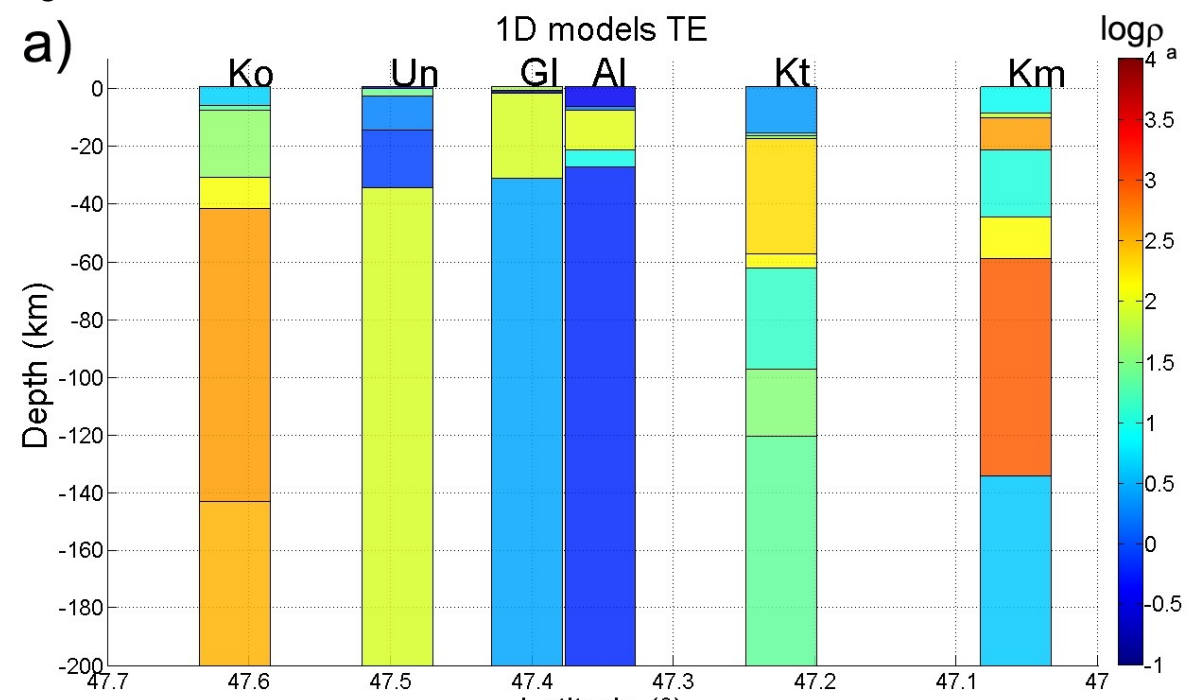

b)

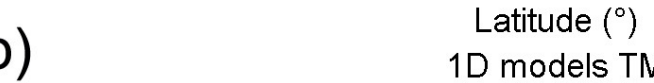

1D models TM

$\log \rho_{a}$

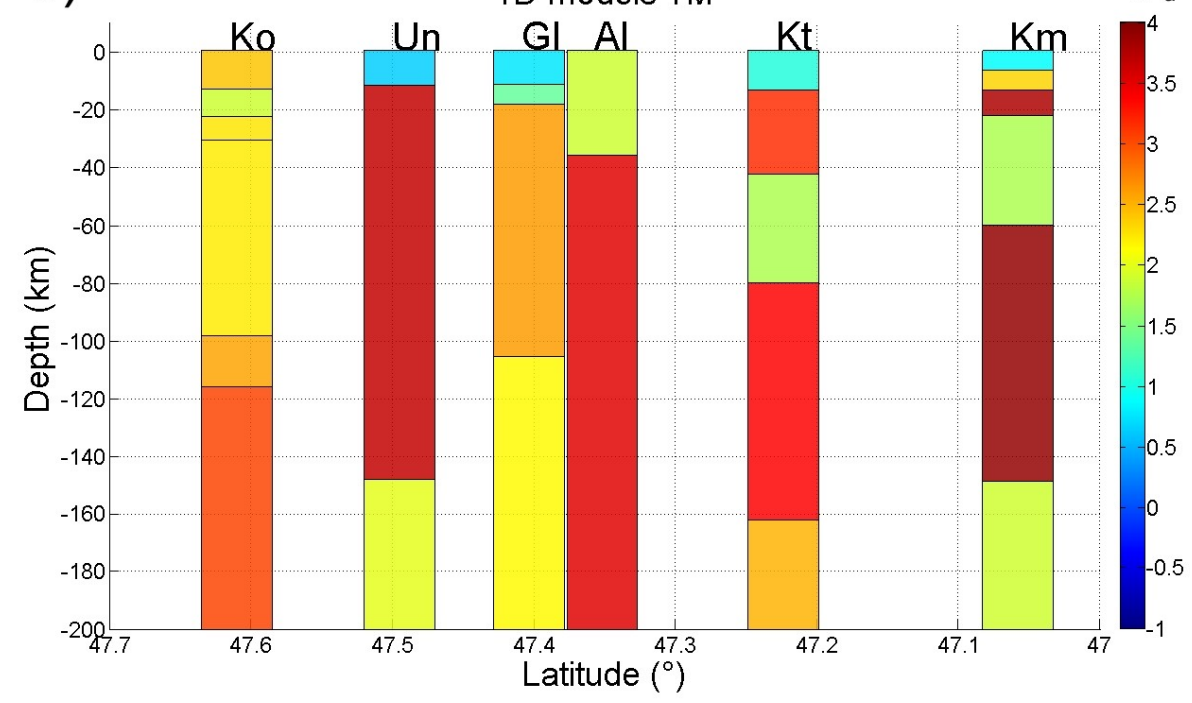

Figure 4.: Resistivity versus depths diagrams as results of 1D inversion (a: TE mode; b: TM mode). The resistivity values are in logarithmic scale. 

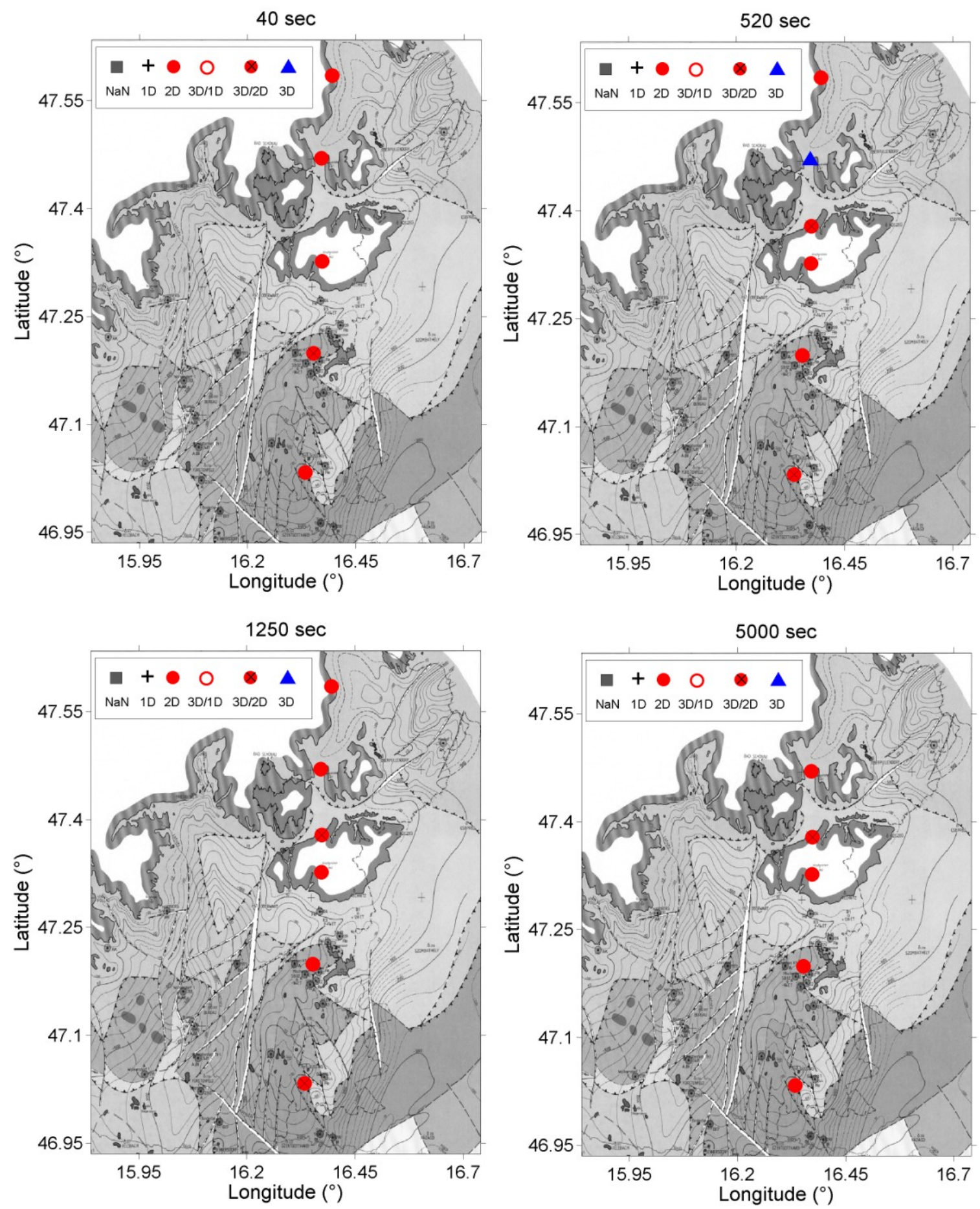

Figure 5.: The Bahr-Q invariants along the MT sites for four frequencies. Symbol of NaN marks the nonclassifiable value. 

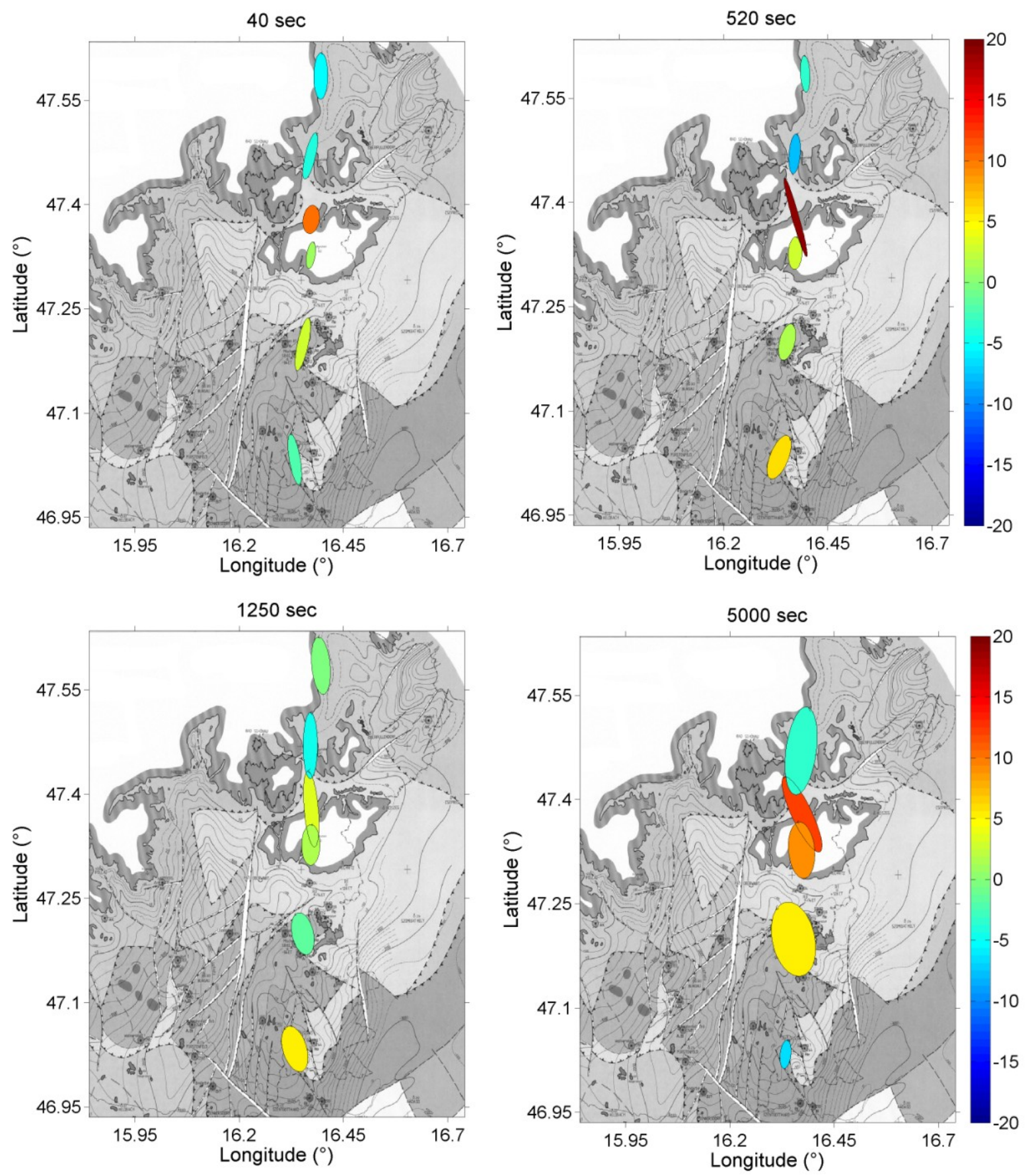

Figure 6.: The phase-tensor ellipses along the MT sites for four frequencies. The fill of ellipses represent by the $\beta_{p}$ skew angle in degree. 

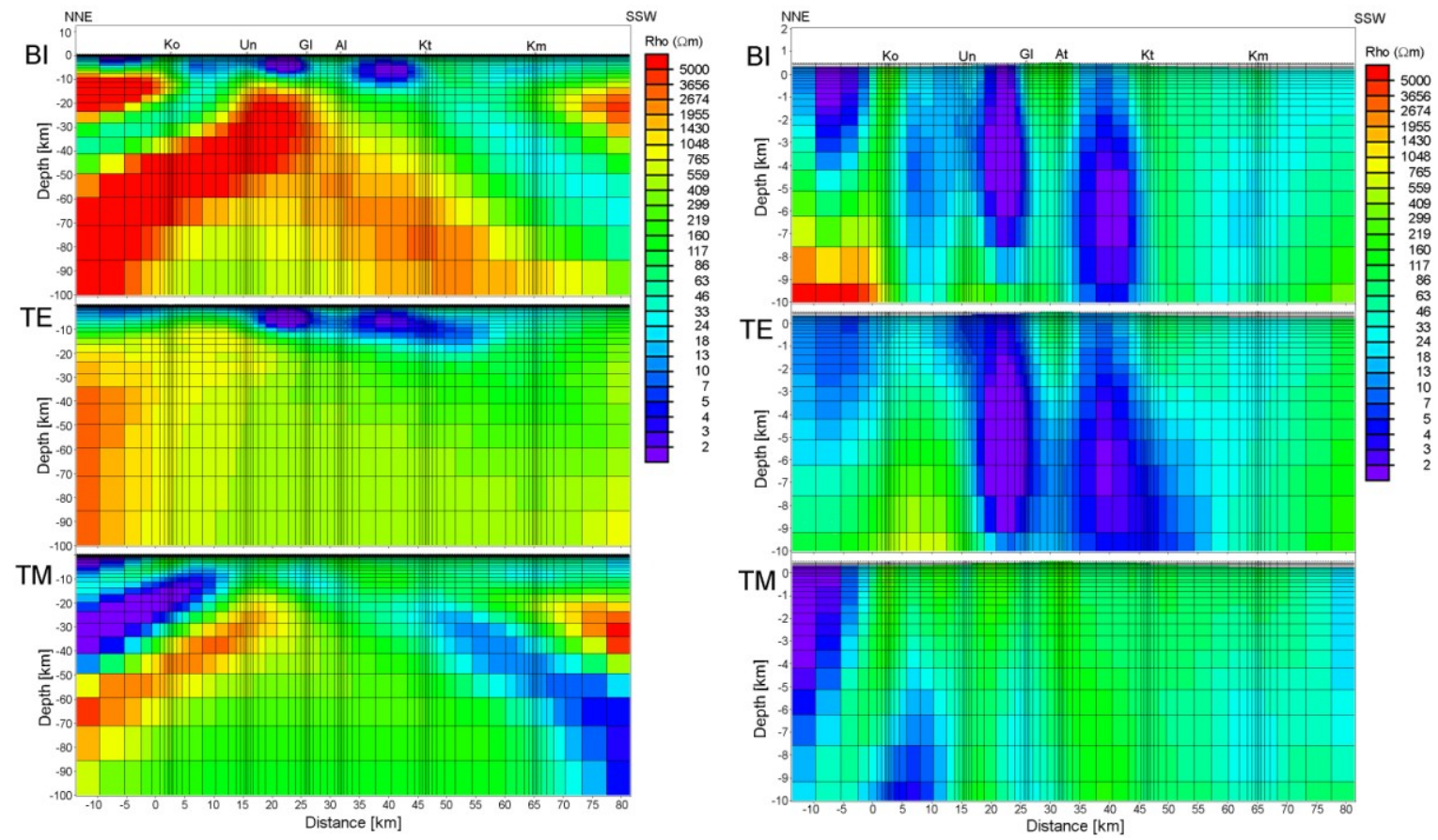

Figure 7.: 2D inversion (BI-bimodal, TE-transversal electric mode, TM-transversal magnetic mode) along the profile of MT sites for depth of $200 \mathrm{~km}(7 \mathrm{a})$ and $10 \mathrm{~km} \mathrm{(7b)} \mathrm{(with} \mathrm{WinGLink} \mathrm{program,} \mathrm{code} \mathrm{Rodi} \mathrm{and} \mathrm{Mackie,}$ 2001). The Root mean square values: BI: $4.01 \%$, TE: $2.65 \%$, TM: $4.7 \%$

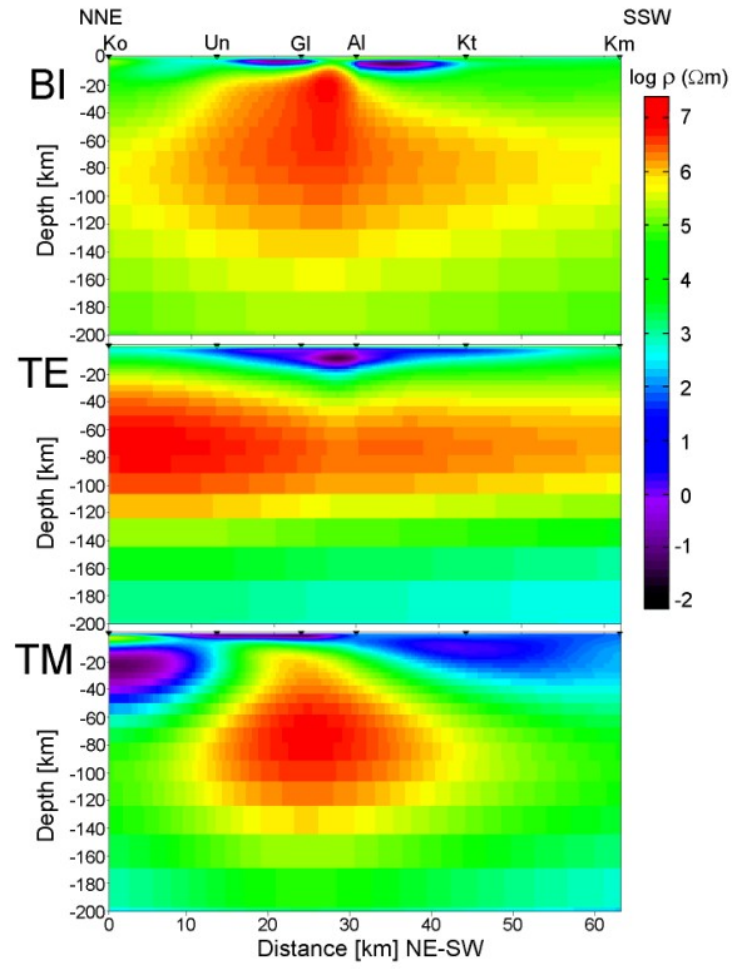

Figure 8.: 2D REBOCC code inversion (BI, TE and TM) along the profile of MT sites till to depth of $200 \mathrm{~km}$. Root mean square values: $\mathrm{BI}-7.73 \%$, TE- $7.06 \%$, TM- $4.77 \%$ 


\begin{tabular}{|c|c|c|c|c|c|c|c|c|c|c|c|c|}
\hline & \multicolumn{12}{|c|}{ MT sites } \\
\hline & \multicolumn{2}{|c|}{ Kobersdorf (Ko) } & \multicolumn{2}{|c|}{ Unterrabnitz (Um) } & \multicolumn{2}{|c|}{ Glasshütten (GI) } & \multicolumn{2}{|c|}{ Althodis (Al) } & \multicolumn{2}{|c|}{ Kotezicken (Kt) } & \multicolumn{2}{|c|}{ Kleinmürbish (Km) } \\
\hline & TE & TM & TE & TM & TE & TM & \begin{tabular}{l|l}
$\mathrm{TE}$ \\
\end{tabular} & TM & TE & TM & $\overline{T E}$ & TM \\
\hline rho1 & 21 & 527 & 3 & 21 & 165 & 26 & 3 & 200 & 13 & 43 & 34 & 31 \\
\hline rho2 & 71 & 200 & 85 & 5358 & 1 & 78 & 10 & 4100 & 41 & 2095 & 189 & 760 \\
\hline rho3 & 119 & 389 & 10 & 246 & 218 & 757 & 247 & 1572 & 136 & 152 & 743 & 6469 \\
\hline rho4 & 295 & 372 & 6 & 16 & 14 & 323 & 38 & 443 & 419 & 3140 & 42 & 153 \\
\hline rho5 & 765 & 721 & 217 & & & & 4 & & 321 & 622 & 307 & 8256 \\
\hline rho6 & 617 & 1700 & 8 & & & & & & 51 & 71 & 1381 & 205 \\
\hline rho7 & 189 & 402 & & & & & & & 104 & 776 & 20 & \\
\hline rho8 & & 155 & & & & & & & 75 & 95 & 1532445 & \\
\hline h1 & 6632 & 13331 & 718 & 12134 & 1585 & 11730 & 6958 & 36522 & 15983 & 13930 & 9065 & 6708 \\
\hline h2 & 1535 & 9630 & 2681 & 136276 & 745 & 6868 & 1374 & 383095 & 1254 & 29031 & 1678 & 6832 \\
\hline h3 & 23048 & 7902 & 11701 & 443208 & 29601 & 87201 & 13814 & 883795 & 902 & 37577 & 11120 & 8993 \\
\hline h4 & 10802 & 67778 & 19954 & & & & 5702 & & 39822 & 82045 & 22961 & 37788 \\
\hline h5 & 101419 & 17576 & 899999 & & & & & & 4815 & 37729 & 14476 & 88468 \\
\hline h6 & 76073 & 93063 & & & & & & & 35026 & 141943 & 75289 & \\
\hline h7 & & 96565 & & & & & & & 23219 & 279996 & 70306 & \\
\hline
\end{tabular}

Table1.: Table of the layer sequences based on the 1D inversion. The Rho values and thickness of the conductors are colored. 